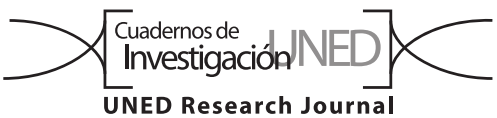

NOTE

\title{
Scorpion body size, litter characteristics, and duration of the life cycle (Scorpiones)
}

\author{
Julián Monge-Nájera \\ Universidad Estatal a Distancia, Vicerrectoría de Investigación, Laboratorio de Ecología Urbana, 2050 San José, Costa Rica; \\ julianmonge@gmail.com
}

Received 01-VIII-2018 • Corrected 20-IX-2018 • Accepted 22-X-2018

\begin{abstract}
There are no studies that quantitatively compare life histories among scorpion species. Statistical procedures applied to 94 scorpion species indicate that those with larger bodies do not necessarily have larger litters or longer life cycles, opposite to some theoretical predictions.
\end{abstract}

Key words: scorpion ecology; multivariate statistics; body size; offspring characteristics, $\mathrm{K}$ and $\mathrm{r}$ strategists.

Life history characteristics, like duration of the reproductive cycle, or the size and number of offspring per female, are determined by poorly documented trade-offs between traits (Roff, Heibo, \& Vøllestad, 2006). In the case of scorpions, there are a few quantitative studies of female and offspring characteristics within populations, but not among species. Larger mothers produce larger litters in Centruroides sculpturatus Ewing, 1928, C. exilicauda Wood, 1863 and Vaejovis spinigerus Wood, 1863 (Brown, 2004; Warburg, 2011), but not in Scorpio maurus Linnaeus, 1758, Nebo hierichonticus Simon, 1872 and Tityus pusillus Pocock, 1893 (Warburg, 2011; de Albuquerque \& de Araujo, 2016). To my knowledge, this is the first study to quantitatively compare life histories among species.

Characteristics for 94 species (Table 1) were extracted from the literature (Polis, 1990: Table 4.2 in pp.184-187; Lourenço, 1992: Table 2 in p. 49); and compared between species that reproduce year-round and seasonally. The majority of species included belong in the Buthidae ( $\mathrm{N}=44$ species) and Vaejovidae ( $\mathrm{N}=19$ species), while other families (Chactidae, Diplocentridae, Ischnuridae, Scorpionidae) had 6-9 species included; the lowest
RESUMEN: "Tamaño corporal, características de la camada y duración del ciclo de vida en los escorpiones (Scorpiones)". No hay estudios que comparen cuantitativamente historias de vida entre especies de escorpiones. Procedimientos estadísticos aplicados a 94 especies indican que las especies con cuerpos más grandes no necesariamente tienen camadas más grandes o ciclos de vida más largos, contrario a algunas predicciones teóricas.

Palabras clave: ecología de escorpiones; estadísticas multivariables; tamaño corporal; características de descendencia, estrategas $\mathrm{K}$ y r. numbers were for Bohriuridae ( $\mathrm{N}=4$ species) and luridae ( $\mathrm{N}=2$ species). Additionally to statistical significance, all trait pairs were also plotted as scattergrams and visually checked for non-linear associations. Tests checked the model proposed by Polis (1990), basically that scorpions range from species with small individuals, short life cycles and abundant offspring ( $r$ strategists or opportunist species, mostly the highly diverse family Buthidae), to larger species that live in more stable habitats, have longer life cycles and care for a few large offspring ( $\mathrm{K}$ or "equilibrium" species, most scorpion families).

Scatter-plots indicated that these scorpion life history characteristics lacked non-linear associations, which means that the linear statistics I used were appropriate to identify any possible correlations. Species that reproduce year-round have significantly shorter first instar periods (Mann-Whitney $\mathrm{U}, \mathrm{p}<0,01$, mostly Buthidae), but contrary to expectation (Polis, 1990), species with larger bodies do not consistently have significantly larger litters, longer life cycles (including gestation, parturition, first instar, longevity) or more molts (Table 1). 
TABLE 1

Pairs of scorpion life history characteristics that lack statistically significant correlations

\begin{tabular}{|c|c|c|c|c|}
\hline First variable & $\begin{array}{c}\text { Second variable } \\
\text { (same units as first variable) }\end{array}$ & Rho & $P$ & $\mathrm{~N}$ \\
\hline Postembryonic development (months) & Litter size & 0,84 & 0,6936 & 23 \\
\hline Parturition (hours) & Gestation & 0,62 & 0,1313 & 7 \\
\hline Age to maturity (months) & Parturition & 0,60 & 0,0897 & 9 \\
\hline Number of molts & Parturition & 0,53 & 0,0662 & 13 \\
\hline Age to maturity (months) & First instar & 0,41 & 0,0757 & 20 \\
\hline Mean longevity (months) & Age to maturity & 0,39 & 0,1862 & 12 \\
\hline Postembryonic development (months) & Parturition & 0,37 & 0,4062 & 6 \\
\hline Body size $(\mathrm{mm})$ & Number of molts & 0,37 & 0,1272 & 18 \\
\hline Age to maturity (months) & Gestation & 0,34 & 0,1792 & 17 \\
\hline Litter size (number of scorplings) & Gestation & 0,30 & 0,0840 & 34 \\
\hline Body size $(\mathrm{mm})$ & First instar & 0,29 & 0,1898 & 21 \\
\hline Body size $(\mathrm{mm})$ & Mean longevity & 0,27 & 0,2091 & 23 \\
\hline Litter size (number of scorplings) & Parturition & 0,23 & 0,3360 & 19 \\
\hline Body size $(\mathrm{mm})$ & Postembryonic development & 0,23 & 0,2797 & 23 \\
\hline Number of molts & First instar & 0,23 & 0,2410 & 28 \\
\hline Body size $(\mathrm{mm})$ & Litter size & 0,21 & 0,2350 & 34 \\
\hline Age to maturity (months) & Litter size & 0,18 & 0,4271 & 21 \\
\hline Postembryonic development (months) & Number of molts & 0,13 & 0,6139 & 15 \\
\hline Body size $(\mathrm{mm})$ & Gestation & 0,13 & 0,4370 & 34 \\
\hline First instar (days) & Litter size & 0,06 & 0,6997 & 42 \\
\hline Age to maturity (months) & Number of molts & 0,06 & 0,8045 & 19 \\
\hline Body size $(\mathrm{mm})$ & Age to maturity & 0,05 & 0,8359 & 15 \\
\hline Mean longevity (months) & Litter size & 0,02 & 0,9227 & 22 \\
\hline
\end{tabular}

$\mathrm{Rho}=$ Spearman rank correlation coefficient, $\mathrm{P}=$ probability, $\mathrm{N}=$ sample size. The following combinations could not be tested because the sample size was below six: Maximum longevity (vs. Postembryonic development, Mean longevity, First instar, Number of molts, Gestation, Litter size and Body size) and mean longevity vs. Parturition.

In scorpions, reproductive seasonality can be highly variable and strongly correlated with environmental factors (e.g., Yamaguti \& Pinto-da-Rocha, 2006). Scorpions may increase survival by having more reproductive episodes each year, explaining the shorter first instar periods found here for species with year-round reproduction. Apparently, seasonal species are more limited and invest in "quality" litters that need more time to reach independence, just as hypothesized earlier by Brown (2003).

Despite the lack of previous studies about maternal size and characteristics of offspring across species, it is known that within a species, not all large females have large litters (by both body mass and length: Brown, 2004; length: Outeda-Jorge, Pinto-da-Rocha, \& Mello, 2009; body mass: Warburg, 2011), and the same trend was found in this study for species: species with larger (i.e. longer) mothers do not consistently have litters with more scorplings or offspring with longer life cycles and better longevity. These results fail to support the $r$ and K model (Polis, 1990; Monge-Nájera \& Lourenço, 1995; Romiguier et al., 2014), a model that is based on few large and longevous individuals, versus many small and short lived individuals: the field is open for a new model. Additionally, the data summarized by Polis (1990) and Lourenço (1992), which are the basis of this note, should be taken with caution because they are of varied quality (some from formal studies, some from personal communications, many from the laboratory, few from the field). I hope this note will inspire future researchers to collect additional, better data, and to test these ideas again.

Ethical, conflict of interest and financial statements: the author declares that he has fully complied with all pertinent ethical and legal requirements, both 
during the study and in the production of the manuscript; that there are no conflicts of interest of any kind; that all financial sources are fully and clearly stated in the acknowledgements section; and that he fully agrees with the final edited version of the article. A signed document has been filed in the journal archives.

\section{ACKNOWLEDGMENTS}

I thank Rocío Azuola and Mónica Chávez for assistance with data processing, and three anonymous reviewers for very helpful suggestions to improve this report.

\section{REFERENCES}

Brown, C.A. (2003). Offspring size-number trade-offs in scorpions: an empirical test of the van Noordwijk and de Jong model. Evolution, 57(9), 2184-2190. DOI: 10.1554/03-014

Brown, C.A. (2004). Life Histories of Four Species of Scorpion in Three Families (Buthidae, Diplocentridae, Vaejovidae) From Arizona and New Mexico. The Journal of Arachnology, 32, 193-207. DOI: 10.1636/M02-56

de Albuquerque, C.M.R., \& de Araujo Lira, A.F. (2016). Insights into reproductive strategies of Tityus (Archaeotityus) pusillus Pocock, 1893 (Scorpiones, Buthidae). Comptes Rendus Biologie, 339(5-6), 179-184. DOI: 10.1016/j. crvi.2016.03.003
Lourenço, W.R. (1992). Les peuplements des Scorpions des Antilles: facteurs historiques et écologiques en association avec les stratégies biodémographiques. Studies on Neotropical Fauna and Environment, 27(1), 43-62. DOI: 10.1080/01650529209360865

Monge-Nájera, J., \& Lourenço, W. (1995). Biogeographic implications of evolutionary trends in onychophorans and scorpions. Biogeographica, 71(4), 179-185.

Outeda-Jorge, S., Pinto-da-Rocha, R., \& Mello, T. (2009). Litter size, effects of maternal body size, and date of birth in South American scorpions (Arachnida: Scorpiones). Zoologia, 26(1), 45-53. DOI: 10.1590/S1984-46702009000100008

Polis, G.A. (1990). The biology of scorpions. California, USA: Standford University Press.

Roff, D.A., Heibo, E., \& Vøllestad, L.A. (2006). The importance of growth and mortality costs in the evolution of the optimal life history. Journal of Evolutionary Biology, 19(6), 1920-1930. DOI: 10.1111/j.1420-9101.2006.01155.x

Romiguier, J., Gayral, P., Ballenghien, M., Bernard, A., Cahais, V., Chenuil, A., ... Loire, E. (2014). Comparative population genomics in animals uncovers the determinants of genetic diversity. Nature, 515(7526), 261-271. DOI: $10.1038 /$ nature 13685

Warburg, M.R. (2011). Scorpion reproductive strategies, allocation and potential; a partial review. European Journal of Entomology, 108(2), 173-181. DOI: 10.14411/ eje. 2011.023

Yamaguti, H.Y., \& Pinto-da-Rocha, R. (2006). Ecology of Thestylus aurantiurus of the parque Estadual da Serra da Cantareira, Sao Paulo, Brazil (Scorpiones, Bothriuridae). Journal of Arachnology, 34(1), 214-220. DOI: 10.1636/ T04-37.1 